\title{
Enhanced cooperation in property matters in the EU and non-participating Member States
}

\author{
Anna Wysocka-Bar ${ }^{1}$
}

Published online: 21 May 2019

(C) The Author(s) 2019

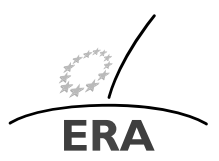

EUROPÄISCHE RECHTSAKADEMIE ACADEMY OF EUROPEAN LAW ACADEMIE DE DROIT EUROPEEN ACCADEMIA DI DIRITTO EUROPEO
TRIER - TREYES - TREVIRI

\begin{abstract}
This article briefly presents the attitude towards same sex-marriages and registered partnerships of legislators in those EU Member States which have decided not to participate in the adoption of EU regulations concerning property matters for spouses and registered partners. It also provides an overview of these regulations in order to indicate which provisions have triggered such decisions. Finally, it points out some examples of clashes resulting from the different systems being applied in participating Member States and non-participating Member States.
\end{abstract}

Keywords Enhanced cooperation - Same-sex marriages - Registered partnerships · Property regimes

\section{Introduction}

In 2011, the European Commission submitted two proposals concerning property matters, ${ }^{1}$ one concerning marriages and one concerning registered partnerships. At some point it became clear that there would be no unanimity among the Member States as required by Art. 81(3) of the Treaty on the Functioning of the European Union (TFEU). Consequently, some Member States informed the Commission about

\footnotetext{
${ }^{1}$ Proposal for a Council Regulation on jurisdiction, applicable law and the recognition and enforcement of decisions in matters of matrimonial property regimes, COM (2011) 126 final (2011 Proposal on Marriages) and the Proposal for a Council Regulation on jurisdiction, applicable law and the recognition and enforcement of decisions regarding the property consequences of registered partnerships, COM (2011) 127 final (2011 Proposal on Registered Partnerships, both referred to as the 2011 Proposals).
}

\footnotetext{
A. Wysocka-Bar anna.wysocka@uj.edu.pl

1 Jagiellonian University, Krakow, Poland
} 
their willingness to establish enhanced cooperation. In 2016, the Commission presented new proposals. ${ }^{2}$ Following the giving of Parliament's consent, ${ }^{3}$ a decision to authorise enhanced cooperation was adopted. ${ }^{4}$ Parliament approved the Commission proposals without any amendments. ${ }^{5}$ Subsequently, the Council adopted two twin regulations. ${ }^{6}$ As Recitals 11 of the regulations indicate, Belgium, Bulgaria, the Czech Republic, Germany, Greece, Spain, France, Croatia, Italy, Luxembourg, Malta, the Netherlands, Austria, Portugal, Slovenia, Finland, Sweden and Cyprus are participating in the enhanced cooperation in the area of the property regimes of international couples and the property consequences of registered partnerships. Hence, $18 \mathrm{Mem}-$ ber States are bound by the regulations, which have been applicable since 29 January 2019 (see Art. 69 and 70 of the regulations). The remaining ten Member States are outside the enhanced cooperation. These are the UK, Ireland, Denmark, Estonia, Latvia, Lithuania, Poland, Slovakia, Hungary and Romania. The latter group may be divided into two sub-categories. The first sub-category consists of the UK, Ireland and Denmark, which traditionally have the special status regarding EU instruments in the field of judicial cooperation in civil and commercial matters that results from the provisions of their respective protocols. ${ }^{7}$ The second sub-category is comprised of the remaining Member States-Estonia (even though this State has already announced its wish to participate in the enhanced cooperation), ${ }^{8}$ Latvia, Lithuania, Poland, Slovakia, Hungary and Romania. This article concentrates on the second sub-category.

\footnotetext{
${ }^{2}$ Proposal for a Council Regulation on jurisdiction, applicable law and the recognition and enforcement of decisions in matters of matrimonial property regimes COM/2016/0106 final and Proposal for a Council Regulation on jurisdiction, applicable law and the recognition and enforcement of decisions in matters of the property consequences of registered partnerships COM/2016/0107 final.

${ }^{3}$ European Parliament legislative resolution of 7 June 2016 on the draft Council decision authorising enhanced cooperation in the area of jurisdiction, applicable law and the recognition and enforcement of decisions on the property regimes of international couples, covering both matters of matrimonial property regimes and the property consequences of registered partnerships (08112/2016 - C8-0184/20162016/0061(NLE)), OJ C 86, 6.3.2018, pp. 150-150.

${ }^{4}$ Council Decision (EU) 2016/954 of 9 June 2016 authorising enhanced cooperation in the area of jurisdiction, applicable law and the recognition and enforcement of decisions on the property regimes of international couples, covering both matters of matrimonial property regimes and the property consequences of registered partnerships, OJ L 159, 16.6.2016, pp. 16-18.
}

${ }^{5}$ European Parliament legislative resolution of 23 June 2016 on the proposal for a Council regulation on jurisdiction, applicable law and the recognition and enforcement of decisions in matters of matrimonial property regimes (COM(2016)0106-C8-0127/2016-2016/0059(CNS)), OJ C 91, 9.3.2018, p. 53-53 and European Parliament legislative resolution of 23 June 2016 on the proposal for a Council regulation on jurisdiction, applicable law and the recognition and enforcement of decisions in matters of the property consequences of registered partnerships (COM(2016)0107-C8-0128/2016-2016/0060(CNS)), OJ C 91, 9.3.2018, p. 54-54.

${ }^{6}$ Council Regulation no. 2016/1103 implementing enhanced cooperation in the area of jurisdiction, applicable law and the recognition and enforcement of decisions in matters of matrimonial property regimes, OJ L 183, 8.7.2016, pp. 1-29 (Regulation on Marriages) and Council Regulation no. 2016/1104 implementing enhanced cooperation in the area of jurisdiction, applicable law and the recognition and enforcement of decisions in matters of the property consequences of registered partnerships, OJ L 183, 8.7.2016, pp. 30-56 (Regulation on Registered Partnerships, both referred to as Regulations).

${ }^{7}$ Protocol nos. 21 and 22 on their position in respect of the area of freedom, security and justice annexed to the Treaty on European Union (TEU) and to the Treaty on the Functioning of the European Union (TFEU).

${ }^{8}$ http://www.europarl.europa.eu/RegData/etudes/ATAG/2016/583835/EPRS_ATA\%282016\%29583835_ EN.pdf (accessed 20.09.2018). 


\section{Attitude towards same-sex marriages and registered partnerships}

It seems that the common feature of the Member States constituting the second subcategory is their more or less conservative approach towards same-sex marriages and/or registered partnerships, which might be perceived as the reason for their decision to object to the adoption of the Regulations.

Latvia provides neither for same-sex marriages nor for registered partnerships. Art. 110 of its Constitution defines marriage as a union between a man and a woman. ${ }^{9}$ In 2015, an attempt to introduce registered partnerships for same-sex couples failed. ${ }^{10}$ Similarly, as regards Lithuania, Art. 38 of its Constitution underlines that a marriage is entered into upon the free consent of a man and a woman. Art. 3.7 of the Civil Code, in consequence, defines marriage as a voluntary agreement between a man and a woman. Interestingly, the Civil Code provides also for the possibility of registering a partnership. However, this institution is reserved for opposite-sex couples. The institution is not used in practice however, despite the Civil Code having been in force since 2001. ${ }^{11}$ As for Poland, Art. 18 of its Constitution provides that marriage as a union between woman and man is under the protection and support of the State. Accordingly, Art. 1 of the Family and Guardianship Code states that a marriage may be contracted between a man and a woman. According to the view of some legal scholars, introducing same-sex marriages and registered partnerships would require an amendment to the Constitution, which is not probable given the current political climate. Past attempts to introduce registered partnerships have failed. ${ }^{12}$ In Slovakia as well, marriage is defined in Art. 1 of the Family Act as a union between a man and a woman. Additionally, in 2014, an amendment to the Constitution entered into force which defines marriage as a union between a man and a woman. The explanatory memorandum to this amendment explicitly states that same-sex couples will not have the possibility of entering into a marriage. ${ }^{13}$ In Romania, in accordance with Art. 258 of the Civil Code, marriage is defined as a union between a man and a woman. There is no legislation on same-sex marriages. Nor are there registered partnerships. Moreover, Art. 227 of the Civil Code provides that marriage between persons of the same sex is prohibited and that marriages between persons of the same sex entered into or contracted abroad by Romanian citizens or by foreigners will not be recognised in Romania. $^{14}$

Hungary and Estonia are particular as in these countries there is legislation on registered partnership, but not on same-sex marriages. In Estonia, according to $\S 1(1)$ of the Family Law Act, a marriage may be contracted between a man and a woman. In 2014 the Registered Partnership Act was adopted. According to $\S 1(1)$ of this, a registered partnership agreement may be entered into between two natural persons. ${ }^{15}$

\footnotetext{
${ }^{9}$ Libina-Egner [18], p. 29.

${ }^{10}$ Kraljić [16], pp. 73-74.

${ }^{11}$ Kudinavičiūté-Michailoviené [17], pp. 29-31.

${ }^{12}$ Kraljić [16], p. 73.

${ }^{13}$ Dobrovodsky [7], pp. 35-36.

${ }^{14}$ See Case C-673/16 Coman EU:C:2018:385.

${ }^{15}$ Uusen-Nacke, Vahaste-Pruul [30], pp. 19-21.
} 
There is no same-sex marriage legislation in Estonia. In Hungary, the 2009 Act on registered partnership defines partners as either two men or two women who declare their intention to enter into a partnership before a registrar. It should be noted that only marriage is mentioned in Art. L of its Constitution, which states that the State protects the institution of marriage as the union of a man and a woman. Furthermore, the Civil Code defines marriage as between one man and one woman. Hence, there is no same-sex marriage in Hungary. ${ }^{16}$ The correlation between not having domestic legislation on registered partnership and/or same sex-marriages and non-participation in the enhanced cooperation and is not a perfect one. Interestingly, even though its Family Code provides solely for opposite-sex marriage, Bulgaria decided to participate in this enhanced cooperation. ${ }^{17}$

When it comes to other Member States outside the enhanced cooperation, Denmark is at the other end of the spectrum, as it was the very first country in the world to introduce a Registered Partnership Act in 1989. The effects of a registered partnership were almost the same as the effects of a marriage, with some exceptions. In 2012 Denmark introduced same-sex marriages with the same legal status as marriages between couples of the opposite sex, again with a few exceptions. The Registered Partnership Act was accordingly repealed, but partnerships contracted in the past may either be converted into a marriage or remain valid. It should be mentioned that opposite-sex couples have never had a right to contract a registered partnership. ${ }^{18}$ In the UK, in England and Wales, opposite-sex marriage, same-sex marriage and exclusively same-sex registered partnership is regulated. ${ }^{19}$ Similarly, in Scotland same-sex marriage and registered partnership is regulated. Registered partnership was introduced in 2004. It was designed with the aim of being the legal equivalent of marriage. The Marriage and Civil Partnership Act of 2014 changed the previous meaning of marriage to include both opposite-sex couples and same-sex couples. As a result, marriage now includes either same-sex or opposite-sex couples, while a registered partnership remains restricted to same-sex couples. ${ }^{20}$ In Ireland, same-sex registered partnerships were introduced in 2010 by the Civil Partnership and Certain Rights and Obligations of Cohabitants Act. ${ }^{21}$ In 2015, as a result of the referendum, the Constitution was amended to provide that marriage may be contacted in accordance with law by two persons without distinction as to their sex. The Marriage Act 2015 abolishes the institution of registered partnerships. Existing registered partnerships remain valid and may be converted into marriages. ${ }^{22}$ Finally it is worth mentioning that also certain Member States participating in enhanced cooperation do not regu-

\footnotetext{
${ }^{16}$ Szeibert [28], p. 27.

${ }^{17}$ Todorova [29], p. 73.

${ }^{18}$ Lund-Andersen [19], p. 18.

${ }^{19}$ Barlow, Lowe [1], p. 19.

${ }^{20}$ Mair [21], p. 19.

${ }^{21}$ Shannon [26], p. 28.

${ }^{22}$ Harding [12], pp. 255-276.
} 
late same-sex marriages, but only registered partnerships (Italy, Greece, Cyprus, the Czech Republic ${ }^{23}$ and Slovenia ${ }^{24}$ ).

\section{Objections towards the regulations in non-participating Member States}

The above suggests that indeed there is a correlation between the conservative approach towards registered partnerships and/or the same-sex marriages by some of the non-participating Member States and their objection to the adoption of the Regulations. The question remains of which feature of the Regulations prevented those Member States to agree on their adoption. The legislative history and particular provisions of the Regulations might suggest answers to this question.

Going back to the 2011 Proposals, it should be recalled that Recital 10 of the 2011 proposal on Marriages stated that it covers issues in connection with matrimonial property regimes. It does not define marriage, which is defined by the national laws of the Member States. It also contained "classical" public policy clauses (Art. 23 and Art. 27(a)). At the same time, Recital 25 of the 2011 proposal on Marriages stated that the courts should not be able to apply the public policy exception or to refuse to recognise or enforce a decision, authentic instrument or legal transaction if the application of the public policy exception would be contrary to the Charter of Fundamental Rights of the European Union (CFR), and in particular to its Art. 21, which prohibits all forms of discrimination. The meaning of this provision will be discussed later as it is included in both regulations. Additionally, Recital 32 of the 2011 proposal on Marriages stated that it respects fundamental rights and observes the principles recognised in the Charter of Fundamental Rights, in particular Art. 7, 9, 17, 21 and 47, which concern, respectively, respect for private and family life, the right to marry and to found a family according to national laws, property rights, the prohibition of any form of discrimination and the right to an effective remedy and to a fair trial. The Member States' courts must apply this regulation in a manner consistent with these rights and principles.

The 2011 proposal on Registered Partnership provided for a modified version of the public policy clause. Apart from the typical wording of its Art. 18(1), in accordance with Art. 18(2) the application of the rule of law designated by the Regulation could not be regarded as contrary to the public policy of the forum merely on the grounds that the law of the forum does not recognise registered partnerships. Similarly, when it came to the recognition and enforcement of foreign judgments Art. 22(a) of the 2011 proposal on Registered Partnerships provided for the general public policy clause. It's Art. 24 stated that the recognition and enforcement of a decision concerning the property consequences of a registered partnership could not be refused merely on the grounds that the law of the Member State addressed did not recognise registered partnerships or did not accord them the same property consequences. Additionally, Recital 21 of the 2011 proposal on Registered Partnerships underlined that

\footnotetext{
${ }^{23}$ Hrusaková [13], p. 16.

${ }^{24}$ Novak [23], pp. 36-37.
} 
the courts must not be able to invoke overriding mandatory provisions or public policy as exceptions in order to set aside the law of another Member State or to refuse to recognise or enforce a decision, an authentic instrument, a legal transaction or a European Certificate of Succession drawn up in another Member State where the application of such an exception would be contrary to the Charter of Fundamental Rights, and in particular its Art. 21, which prohibits all forms of discrimination. Nor could these courts set aside the law applicable to registered partnerships merely on the grounds that the public policy of the forum did not recognise registered partnerships. Also, Recital 23 of the 2011 proposal on Registered Partnerships repeated that it should not be possible in a Member State to refuse the recognition and enforcement of a decision concerning the property consequences of a registered partnership if that Member State's national law does not recognise such partnerships or provides for different consequences with regard to property.

The above provisions underwent significant changes with the intention of addressing the doubts and fears of the "conservative" Member States. ${ }^{25}$ To this end, Art. $1(2)(b)$ of the regulations provide for the exclusion from their scopes of the existence, validity or recognition of - respectively — a marriage and a registered partnership. As indicated above, Recital 17 of the Regulation on Marriages states that it does not define marriage, which is defined by the national laws of the Member States. ${ }^{26}$ Conversely, the Regulation on Registered Partnerships provides for an autonomous definition of a registered partnership in its Art. 3(1)(a). In accordance with Art. 9(1) of the Regulation on Marriages, if a court of the Member State that has jurisdiction pursuant to the provisions of the Regulation holds that, under its private international law, the marriage in question is not recognised for the purposes of matrimonial property regime proceedings, it may decline jurisdiction. Similarly, Art. 9(1) of the Regulation on Registered Partnerships provides that if the law of the forum does not provide for the institution of registered partnership, the court may decline jurisdiction. ${ }^{27}$ Hence a "conservative" Member State would not be "forced" to deal with cases concerning same-sex marriages and registered partnerships. When it comes to the applicable law, Art. 31 of the Regulations provides for a "classical" public policy clause. When it comes to recognition and enforcement, the regulations provide for automatic recognition (Art. 36) and enforcement based on the declaration of enforceability issued in accordance with the procedure provided for by the regulations (Art. 42). The regulations list typical grounds for non-recognition and non-enforcement, including once again a "classical" public policy clause (Art. 37). At the same time, Art. 38 of the Regulations underlines that the grounds of non-recognition and non-enforcement have to be applied in observance of the fundamental rights and principles recognised in the Charter of Fundamental Rights, in particular its Art. 21 (the principle of nondiscrimination). Similarly to Recital 25 , Recital 54 of the regulations explains that it should not be possible to apply the public policy exception in order to refuse to recognise or accept or enforce a decision, an authentic instrument or a court settlement from another Member State when doing so would be contrary to the Charter of Fun-

\footnotetext{
${ }^{25}$ For criticism of that approach, see Dutta [8], p. 157.

${ }^{26}$ On doubts caused by this Recital, see Dutta [8], pp. 148-153.

${ }^{27}$ See Franzina [10], pp. 184-189.
} 
damental Rights, and in particular its Art. 21 on the principle of non-discrimination. The question is how to understand this provision.

A provision which is to some extent similar is to be found in the Divorce (Rome III) Regulation, ${ }^{28}$ as well as in the Succession Regulation, ${ }^{29}$ the former being applied in some "conservative" Member States (Latvia, Lithuania, Hungary and Romania) and the latter being applied in all of the "conservative" Member States. The difference is that the commented-on provisions form only part of the respective preambles (Recital 25 of the Divorce Regulation and Recital 58 of the Succession Regulation), whereas in the regulations, the provision is additionally inserted into the normative part of the regulations as a separate article. Taking into account the views on the normative value of the recitals ${ }^{30}$ it seems that moving this provision from a recital to a separate article is supposed to strengthen its normative value. It has been suggested that the provision referring to Art. 21 of the Charter of Fundamental Rights in the Rome III Regulation is designed to apply to, inter alia same-sex marriages. The following example is given to explain its meaning. When a spouse to a same-sex marriage celebrated in one Member State applies for a divorce in another Member State which does not recognise same-sex marriages, the courts of the latter Member State should not invoke the public policy of the forum as this would violate the prohibition of discrimination on the grounds of sexual orientation expressed in Art. 21 of the Charter of Fundamental Rights. ${ }^{31}$ The Charter of Fundamental Rights serves two aims. On one hand, the application of the law designated as applicable should not violate the public policy of the forum, including fundamental rights established in the Charter of Fundamental Rights. On the other hand, making use of the clause and the resulting setting aside of the law designated as applicable should not be incompatible with the fundamental rights established in the Charter of Fundamental Rights as well. ${ }^{32}$

The application of this standpoint per analogiam to the Regulations (and assuming that all Member States are bound by the Regulations) may be illustrated by the following example: a judgment concerning a "conservative" Member State's citizen (for example an ex-spouse, who wants to divide the property after the divorce) and an immovable property (for example an apartment) located in that Member State issued in another Member State would have to be recognised in the "conservative" Member State without the possibility of any recourse to the public policy clause, as this recourse would be contradictory to the principle of non-discrimination established in the Charter of Fundamental Rights. ${ }^{33}$ The above might raise the fears of the "conservative" Member States that obligatory recognition and enforcement in accordance

\footnotetext{
${ }^{28}$ Council Regulation (EU) No. 1259/2010 of 20 December 2010 implementing enhanced cooperation in the area of the law applicable to divorce and legal separation, OJ L 343, 29.12.2010, pp. 10-16.

${ }^{29}$ Regulation (EU) No. 650/2012 of the European Parliament and of the Council of 4 July 2012 on jurisdiction, applicable law, recognition and enforcement of decisions and acceptance and enforcement of authentic instruments in matters of succession and on the creation of a European Certificate of Succession, OJ L 201, 27.7.2012, pp. 107-134.

${ }^{30}$ Klimas, Vaiciukaite [15], pp. 61-93.

${ }^{31}$ Basedow [2], pp. 147-148. See also González Beilfuss [11], pp. 183-184.

${ }^{32}$ Basedow [2], pp. 147-148.

${ }^{33}$ Compare Clavel, Jault-Seseke [3], p. 237.
} 
with the regulations would in fact lead to the transfer to their territories of the effects of foreign same-sex marriages and registered partnerships and, therefore, also result in the unification by the EU of the substantive family laws of the Member States, irrespective of the lack of appropriate competences. ${ }^{34}$

\section{Possible clashes}

\subsection{Introduction}

The fact that the regulations were adopted under the enhanced cooperation procedure has differing implications depending on the Member State. From the perspective of a participating Member State, ${ }^{35}$ its authorities will, in general, apply the regulations in order to assert their jurisdiction and find an applicable law in all cases, as the regulations apply erga omnes - including in situations involving persons who have their habitual residence in non-participating Member States (or even outside the EU) or in situations which concern assets located in non-participating Member States (or States outside the EU). ${ }^{36}$ These authorities will also apply the regulations to the recognition and enforcement of judgments issued in another participating Member State. When it comes to the recognition and enforcement of judgments issued in non-participating Member State the same "domestic" rules will apply as to judgments coming from outside the EU. However, one should not forget Art. 62(2) of the regulations, which state that the regulations do not affect the application of bilateral or multilateral agreements to which one or more (participating) Member States are parties. Hence, bilateral conventions concluded by a participating Member State with a non-participating Member State take precedence over the regulations. For example, bilateral agreements concluded by Poland with Bulgaria (1961), the Czech Republic and Slovakia (1987), France (1969), Austria (1963), Slovenia and Croatia (1960) will take precedence over the regulations and will still be applied by the participating Member State, instead of the regulations. The conventions indicated above are convention triple, so just like the regulations they cover the jurisdiction, applicable law and recognition and enforcement of judgments. It might be assumed that these bilateral conventions do not cover either the matrimonial property regimes of same-sex spouses or the property consequences of the registered partnerships, as they were negotiated and signed in the $1960 \mathrm{~s}-1980 \mathrm{~s}^{37}$ As a result, in such cases the regulations will be applied under the assumption that these matters are outside the scope of the bilateral conventions. Art. 62(3) of the Regulation on Marriages underlines that it does not

\footnotetext{
${ }^{34}$ See Mostowik [22], pp. 108-109.

${ }^{35}$ In contrast with the Rome III Regulation, the regulations do not use the term "participating Member State" (meaning a Member State which participates in enhanced cooperation (see Article 3(1) of the Rome III)). However it is rational to assume that a Member State within the meaning of the Regulations is only a participating Member State.

${ }^{36}$ Franzina [10], pp. 164 and 190.

${ }^{37}$ For an opposite conclusion with respect to the Hague Convention of 14 March 1978 on the Law Applicable to Matrimonial Property Regimes see van Loon [31], pp. 514-515.
} 
preclude the application of the Nordic Conventions in force between Denmark, Finland, Iceland, Norway and Sweden in so far as they provide for simplified and more expeditious procedures for the recognition and enforcement of decisions in matters of matrimonial property regime. ${ }^{38}$ No similar provision is included in the Regulation on Registered Partnership, which suggests that the Nordic Convention does not apply to registered partnerships. The question of whether the Nordic Convention applies to same-sex marriages seems more complicated. ${ }^{39}$

From the perspective of a non-participating Member State, its authorities will apply "domestic" rules (including any bilateral conventions) to assert their jurisdiction, then find an applicable law and recognise or enforce a judgment issued in another Member State. These rules may differ as between non-participating Member States and also in comparison to those provided for in the regulations. Due to the foregoing there may be potential clashes between the rules applied in a participating Member State and a non-participating Member State.

\subsection{Jurisdiction}

When it comes to jurisdiction the regulations provide for exhaustive rules-with no place left for "domestic" rules. ${ }^{40}$ The regulations provide for the jurisdiction of the courts of a participating Member State seized of succession matters in accordance with the Succession Regulation (Art. 4 regulations) and of matrimonial matters in accordance with the Brussels II bis Regulation (Art. 5(1) regulations), as well as of cases other than those connected with succession/matrimonial matters or when, based on the said provisions, no participating Member State has jurisdiction. In this case, the jurisdictional rule creates a "cascade" of common habitual residence, last common habitual residence, insofar as one of the spouses still resides there or the habitual residence of the respondent and spouses' common nationality. In the above-mentioned cases, once ascertained, the jurisdiction of the court of a participating Member State (for example in accordance with Art. 6 regulations based on the common habitual residence of the divorcing spouses) covers all the assets of the spouses, including immovable property, no matter whether located in a participating Member State or a non-participating Member State (or even outside the EU).

At the same time, in matters concerning matrimonial property regimes, a nonparticipating Member State may and probably still will-in this regard, the example of Poland can be given - stick to the traditional rule that immovable property located within its territory falls under the exclusive jurisdiction rule. ${ }^{41}$ As a result, it may happen that the courts of two different Member States will have jurisdiction: in a participating Member State, based on the regulations (for example, the above-mentioned Art. 6), and in a non-participating Member State, based on its "domestic" rules (based

\footnotetext{
38 Jänterä-Jareborg [14], pp. 733-752.

${ }^{39}$ Wautelet [32], p. 158.

${ }^{40}$ Franzina [10], pp. 164-165.

${ }^{41}$ An opposite situation is commented on in Franzina [10], p. 191. It seems however that such an opposite situation is less likely to appear in practice, as the exclusive jurisdiction for domestic immovable property often goes hand in hand (at least in Poland it does) with lack of jurisdiction with respect to immovable property located abroad.
} 
on the location of immovable property). In this case, from the perspective of a participating Member State, the provision on limitation of proceedings (see Art. 13 of the regulations) will not allow the court to remove this immovable property from its proceeding, as the provision concerns only cases linked with succession. It could be suggested that Art. 13 could have been modelled on the similar provision in the Succession Regulation and, therefore, have been given a broader scope. Additionally, the lis pendens rule (see Art. 17 of the regulations) does not apply to proceedings in a non-participating Member State ${ }^{42}$ and, therefore, seems to require the court to hear the case even when there is an obvious risk that the judgment will not be recognised in the non-participating Member State, where the immovable property is located, either because of the grounds for refusal resulting from the violation of exclusive jurisdiction or because of a domestic judgment in the same case (even a later one).

\subsection{Applicable law}

When it comes to the applicable law the regulations allow for a limited choice of applicable law (Art. 22 of the Regulations) and in the absence of choice, provide for a "cascade" rule with respect to matrimonial property regimes (the spouses' first common habitual residence after the conclusion of the marriage; common nationality at the time of the conclusion of the marriage; or the closest connection at the time of the conclusion of the marriage-Art. 26(1) of the Marriage Regulation) or the place of registration for registered partnerships (Art. 26(1) Registered Partnership Regulation). In general, the rule of immutability (crystallisation) of the applicable law dominates in the regulations. By way of exception and upon application by either spouse/partner, the law of the last common habitual residence may govern the property regime if certain requirements are met (see Art. 26(3) of the regulations). Due to the foregoing and the universality principle (see Art. 20 of the regulations), it may happen that the applicable law will be the law of a non-participating Member State. ${ }^{43}$ In the case of same-sex marriages, it seems that if the substantive law of a non-participating Member State is designated as applicable, it may happen that the rules concerning (only opposite-sex) matrimonial property may be applied by the use of adaptation. In probability, a public policy clause may also be used against such a substantive law. As Art. 32 of the regulations provides for the exclusion of renvoi, the courts of a participating Member State will not be obliged to verify the content of the "domestic" private international law rules of a non-participating Member State. Legal advisors should on the other hand know it when advising on marital agreements. ${ }^{44}$

It should be mentioned here that the "domestic" private international law rules of non- participating Member States are not a coherent system that may be opposed to the rules of an enhanced cooperation area. Instead they provide for the whole range of different solutions with respect to the applicable law concerning the mutability or immutability rules, the admissibility of choice of the applicable law and connecting factors. Hence, it might happen that for example, the responsibility of one spouse for

\footnotetext{
${ }^{42}$ On lis pendens in the Regulations see Franzina [10], p. 191.

${ }^{43}$ Coester-Waltjen [4], p. 199.

${ }^{44}$ Coester-Waltjen [4], p. 201.
} 
the liabilities of the other would be governed by different substantive laws depending on the jurisdiction hearing the case. In Latvia matrimonial regimes are governed by lex fori provided that the spouses have their domicile in Latvia. If the spouses have their domicile abroad, but the property is located in Latvia, Latvian law applies also. ${ }^{45}$ In Lithuania, the "cascade" provides for the application of the law of the state of the common domicile of the spouses and common nationality. The limited choice of the applicable law is admitted. The spouses are allowed to choose the law applicable to their matrimonial agreement. The choice is limited to common or intended domicile, the place of the celebration of marriage or the nationality of one of the spouses. ${ }^{46}$ In Poland, the "cascade" provides for the application of the law of the common nationality of the spouses, common domicile, common habitual residence and finally the law of the country with which both spouses are most closely connected. Spouses may choose the law applicable to their property relations. This choice is limited to the national law of either of the spouses or the law of the country in which one of them is domiciled or habitually resident. ${ }^{47}$ In Slovakia, the two steps of the "cascade" are common nationality and Slovak law. Matrimonial agreements are governed by the law applicable to the property relations of the spouses at the time when the agreement was concluded. ${ }^{48}$ In Hungary, the "cascade" provides for the application of the law of common nationality, common habitual residence, last common habitual residence and lex fori. The choice of the applicable law is limited to the nationality of one of the spouses, the habitual residence of one of the spouses and lex fori. ${ }^{49}$ In Romania the law applicable to the effects of marriage applies to property relations. The "cascade" provides for the application of the law of the common habitual residence, common nationality and the place of the celebration of marriage. A limited choice of applicable law is admitted. ${ }^{50}$ Estonian private international law provides for a limited choice of the applicable law (residence or the nationality of one of the spouses) and in the absence of choice, the property relations of the spouses are governed by the law applicable to the general legal consequences of the marriage at the time of the conclusion of the marriage. The "cascade" indicates to the common residence of the spouses, common nationality, the last common residence and the closest connection. ${ }^{51}$ In the UK (England and Wales) ${ }^{52}$ and Ireland, the lex fori is applied. In Scotland, the law applicable would be lex situs or lex domicilii depending on the

\footnotetext{
${ }^{45}$ Rudevska [25], pp. 2261-2262.

${ }^{46}$ Ravluševičius [24], p. 2293.

${ }^{47}$ Mączyński [20], p. 2430.

${ }^{48}$ Stefankova [27], p. 2501.

${ }^{49}$ Act XXVIII of 2017 on private international law. Available at http://njt.hu/translated/doc/J2017T0028P 20180102_FIN.pdf (accessed 20.09.2018).

${ }^{50}$ Cotiga-Raccah [5], p. 2450.

${ }^{51}$ See Private International Law Act of 27 March 2002 available at https://www.riigiteataja.ee/en/eli/ 514032016002/consolide (accessed 20.09.2018)

${ }^{52}$ See Bar Council of England and Wales, Brussels Office, Forum on Judicial Cooperation in Civil Matters, Brussels, 2 December 2008, Session IV, Family Law and the Law of Succession, Sect. 11. Available at http://www.europarl.europa.eu/document/activities/cont/200811/20081125ATT43039/ 20081125ATT43039EN.pdf (accessed 20.09.2018).
} 
immovable or movable character of the asset. ${ }^{53}$ In Denmark ${ }^{54}$ the matrimonial property of spouses is governed by the law of the domicile of the husband at the time of concluding the marriage. When it comes to same-sex marriages/registered partnerships, it was proposed in the legal literature that a limited choice of the applicable law and in the absence of the choice, the law of the first common domicile or place of registration.

\subsection{Recognition and enforcement}

When it comes to the recognition and enforcement of judgments, the regulations provide for automatic recognition (Art. 36) and enforcement based on a declaration of enforceability issued in accordance with the procedure provided for by the regulations. The regulations provide for typical grounds for non-recognition and nonenforcement (see Art. 37), with the exception of Art. 38, which was discussed above. It should be noted that the regulations apply only to judgments issued in other participating Member States. Judgments issued in a non-participating Member State will be recognised and enforced on the basis of "domestic" private international law provisions or bilateral agreements. Similarly, the recognition and enforcement of judgments issued in a participating Member State will be subject to the "domestic" rules of a non-participating Member State or respective bilateral agreements. This - together with different rules on jurisdiction - may lead to the non-recognition and non-enforcement of judgments issued in a participating Member State in a nonparticipating Member State.

\section{Conclusions}

In accordance with Art. 20(1) of the Treaty on the EU, and as Recital 13 of the regulations remains in effect, enhanced cooperation is open to all Member States. It is hard to expect that any conservative Member State (except perhaps for Estonia) would join before same-sex marriages and/or registered partnerships are introduced into their "domestic," substantive laws. For the time being, there is an area of enhanced cooperation in property matters in the EU and a group of remaining Member States with their own "domestic" private international law rules with that respect. Clashes between these systems are inevitable. This undermines the objective of the regulations, which is to provide married couples/registered partners with legal certainty as to their property and offer them a degree of predictability (as Recital 15 of the regulations promises).

Publisher's Note Springer Nature remains neutral with regard to jurisdictional claims in published maps and institutional affiliations.

Open Access This article is distributed under the terms of the Creative Commons Attribution 4.0 International License (http://creativecommons.org/licenses/by/4.0/), which permits unrestricted use, distribution, and reproduction in any medium, provided you give appropriate credit to the original author(s) and the source, provide a link to the Creative Commons license, and indicate if changes were made.

${ }^{53}$ Crawford, Carruthers [6], p. 377.

${ }^{54}$ Fogt [9], p. 2034. 


\section{References}

1. Barlow, A., Lowe, N.: England Wales. In: Boele-Woelki, K., Mol, Ch., van Gelder, E. (eds.) Family Law in Action. Informal Relationships, vol. V, p. 19. Intersentia, Cambridge (2015)

2. Basedow, J.: European divorce law: comments on the Rome III regulation. In: Verbeke, A.-L., Scherpe, J., Declerck, Ch., Helms, T., Senaeve, P. (eds.) Confronting the Frontiers of Family and Succession Law: Liber Amicorum Walter Pintens, pp. 135-150. Intersentia, Cambridge (2012)

3. Clavel, S., Jault-Seseke, F.: Public interest considerations-changes in continuity. In: Comments on Articles 30 and 21 of the Regulations on Patrimonial Consequences of Marriages and Registered Partnerships. Yearbook of Private International Law XIX, pp. 233-246 (2017/2018)

4. Coester-Waltjen, D.: Connecting factors to determine the law applicable to matrimonial property regimes. Yearbook of Private International Law XIX, pp. 195-211 (2017/2018)

5. Cotiga-Raccah, A.: Romania. In: Basedow, J., Rühl, G., Ferrari, F., In: de Miguel Asensio, P. (eds.) Encyclopedia of Private International Law. National Reports, vol. 3, pp. 2442-2451. Edward Elgar, Cheltenham Glos (2017)

6. Crawford, E., Carruthers, J.: International Private Law. A Scots Perspective. Green, London (2010)

7. Dobrovodsky, R.: Slovakia. In: Boele-Woelki, K., Mol, Ch., van Gelder, E. (eds.) Family Law in Action. Informal Relationships, vol. V, pp. 35-36. Intersentia, Cambridge (2015)

8. Dutta, A.: Beyond husband and wife-new couple regimes and the European property regulations. Yearbook of Private International Law XIX, pp. 145-158 (2017/2018)

9. Fogt, M.: Denmark. In: Basedow, J., Rühl, G., Ferrari, F., de Miguel Asensio, P. (eds.) Encyclopedia of Private International Law. National Reports, vol. 3, pp. 2019-2036. Edward Elgar, Cheltenham Glos (2017)

10. Franzina, P.: Jurisdiction in matters relating to property regimes under EU private international law. Yearbook of Private International Law XIX, pp. 159-194 (2017/2018)

11. González Beilfuss, C.: The proposals on council regulations in matters of matrimonial property regimes and on the property consequences of registered partnerships: interactions between private international law and substantive law. In: Lauroba Lacasa, E., Ginebra Molins, M. (eds.) Régimes matrimoniaux de participation aux acquêts et autres mécanismes participatifs entre époux en Europe, pp. 171-187. Société de législation comparée, Paris (2016)

12. Harding, M.: Marriage Equality: A Seismic Shift for Family Law in Ireland. International Survey of Family Law, pp. 255-276 (2016)

13. Hrusaková, M.: Czech Republic. In: Boele-Woelki, K., Mol, Ch., van Gelder, E. (eds.) Family Law in Action. Informal Relationships, vol. 5, pp. 16-17. Intersentia, Cambridge (2015)

14. Jänterä-Jareborg, M.: Inter-Nordic Exceptions in EU Regulations on matters of Family and Inheritance Law. Legal "Irritants” or Necessary Concessions in the Citizens' Interest? In: Verbeke, A.-L., Scherpe, J., Declerck, Ch., Helms, T., Senaeve, P. (eds.) Confronting the Frontiers of Family and Succession Law: Liber Amicorum Walter Pintens, pp. 733-752. Intersentia, Cambridge (2012)

15. Klimas, T., Vaiciukaite, J.: The law of recitals in European community legislation. ILSA J. Int. Comp. Law 15, 61-93 (2008)

16. Kraljić, S.: Same-sex partnerships in eastern Europe: marriage, registration or no regulation? In: Boele-Woelki, K., Fuchs, A. (eds.) Same Sex Relationships and Beyond. Gender Matters in the EU, pp. 55-75. Intersentia, Cambridge (2017)

17. Kudinavičiūté-Michailoviené, I.: Lithuania. In: Boele-Woelki, K., Mol, Ch., van Gelder, E. (eds.) Family Law in Action. Informal Relationships, vol. V, pp. 29-31. Intersentia, Cambridge (2015)

18. Libina-Egner, I.: Latvia. In: Boele-Woelki, K., Mol, Ch., van Gelder, E. (eds.) Family Law in Action. Informal Relationships, vol. V, p. 29. Intersentia, Cambridge (2015)

19. Lund-Andersen, I.: Denmark. In: Boele-Woelki, K., Mol, Ch., van Gelder, E. (eds.) Family Law in Action. Informal Relationships, vol. V, p. 18. Intersentia, Cambridge (2015)

20. Mączyński, A.: Poland. In: Basedow, J., Rühl, G., Ferrari, F., de Miguel Asensio, P. (eds.) Encyclopedia of Private International Law. National Reports, vol. 3, pp. 2421-2433. Edward Elgar, Cheltenham Glos (2017)

21. Mair, J.: Scotland. In: Boele-Woelki, K., Mol, Ch., van Gelder, E. (eds.) Family Law in Action. Informal Relationships, vol. V, p. 33-35. Intersentia, Cambridge (2015)

22. Mostowik, P.: O uzasadnionych powodach nieprzystąpienia Polski do rozporządzeń UE nr 2016/1103 i 2016/1104 dotyczących wewnętrznych i zewnętrznych relacji małżonków i rejestrowanych partnerów [On the justified reasons for Poland's non-accesssion to the regulations number 2016/1103 and 2016/1104 concerning internal and external relations of spouses and registered partners]. In: 
Gołaczyński, J., Popiołek, W. (eds.) Kolizyjne i Procesowe Aspekty Prawa Rodzinnego [Conlict of Laws and Procedural Aspects of Family Law], pp. 105-115. C.H. Beck Verlag, Warszawa (2019)

23. Novak, B.: Slovenia. In: Boele-Woelki, K., Mol, Ch., van Gelder, E. (eds.) Family Law in Action. Informal Relationships, vol. V, pp. 36-37. Intersentia, Cambridge (2015)

24. Ravluševičius, P.: Lithuania In: Basedow, J., Rühl, G., Ferrari, F., de Miguel Asensio, P. (eds.) Encyclopedia of Private International Law. National Reports, vol. 3, pp. 2286-2296. Edward Elgar, Cheltenham Glos (2017)

25. Rudevska, B.: Latvia. In: Basedow, J., Rühl, G., Ferrari, F., de Miguel Asensio, P. (eds.) Encyclopedia of Private International Law. National Reports, vol. 3, pp. 2252-2264. Edward Elgar, Cheltenham Glos (2017)

26. Shannon, G.: Ireland. In: Boele-Woelki, K., Mol, Ch., van Gelder, E. (eds.) Family Law in Action. Informal Relationships, vol. V, pp. 28-29. Intersentia, Cambridge (2015)

27. Stefankova, N.: Slovakia. In: Basedow, J., Rühl, G., Ferrari, F., de Miguel Asensio, P. (eds.) Encyclopedia of Private International Law. National Reports, vol. 3, pp. 2492-2503. Edward Elgar, Cheltenham Glos (2017)

28. Szeibert, O.: Hungary. In: Boele-Woelki, K., Mol, Ch., van Gelder, E. (eds.) Family Law in Action. Informal Relationships, vol. V, p. 27. Intersentia, Cambridge (2015)

29. Todorova, V.: Bulgaria. In: Boele-Woelki, K., Mol, Ch., van Gelder, E. (eds.) Family Law in Action. Informal Relationships, vol. V, p. 15. Intersentia, Cambridge (2015)

30. Uusen-Nacke, T., Vahaste-Pruul, S.: Estonia. In: Boele-Woelki, K., Mol, Ch., van Gelder, E. (eds.) Family Law in Action. Informal Relationships, vol. V, p. 19-21. Intersentia, Cambridge (2015)

31. van Loon, H.: On the applicability of Hague Conventions on private international law to same-sex marriages. In: Moreno Rodriguez, J., Lima Marques, C. (eds.) Los servicios en el Derecho Internacional Privado: Jornadas de la ASADIP 2014, Porto Alegre, 30-31 de octobre, pp. 507-523. Gráfica e Editora RJR, Porto Alegre (2014)

32. Wautelet, P.: Private international law aspects of same-sex marriages and partnerships in Europe. Divided we stand? In: Boele-Woelki, K., Fuchs, A. (eds.) Legal Recognition of Same-Sex Relationships in Europe, pp. 143-187. Intersentia, Cambridge (2012) 